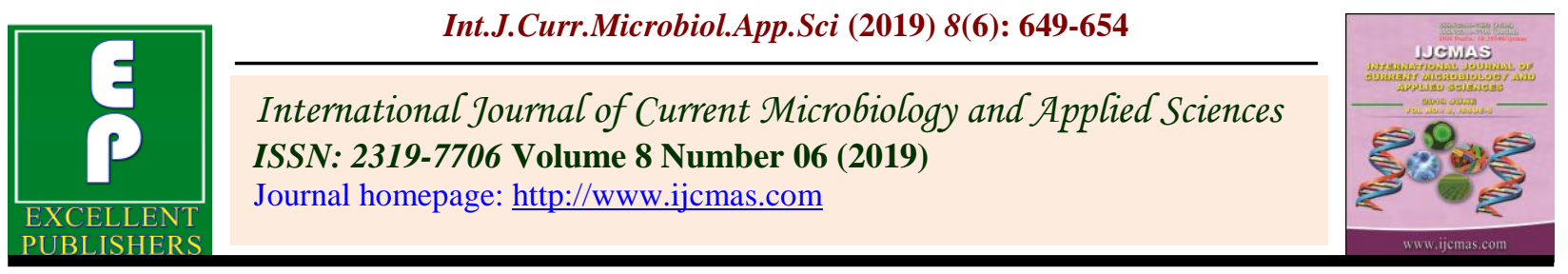

Original Research Article

https://doi.org/10.20546/ijcmas.2019.806.075

\title{
Genetic Diversity Analysis in CMS Lines of Chilli (Capsicum annuum L.)
}

\author{
M. Vinodhini*, V.V. Dalvi, S.S. Desai and S.V. Sawardekar \\ Department of Agriculture Botany, College of Agriculture,, Dr. Balasaheb Sawant Konkan \\ Krishi Vidyapeeth, Dapoli- 415712 (M.S.), India
}

*Corresponding author

\begin{tabular}{|c|c|}
\hline & A B S T R A C T \\
\hline Keywords & \\
\hline $\begin{array}{l}\text { Chilli, CMS, } \\
\text { Genetic diversity } \\
\text { and ISSR marker }\end{array}$ & \multirow{3}{*}{$\begin{array}{l}\text { Cytoplasmic Male sterility (CMS) is increasingly utilized for hybrid seed production of } \\
\text { chilli (Capsicum annuum L.). Eight CMS and eight maintainer lines were studied for } \\
\text { genetic diversity using ISSR markers. The ISSR analysis revealed substantial } \\
\text { polymorphism in chilli. The results of the present study indicated the efficiency of ISSR } \\
\text { markers in investigating genetic variability at molecular level, which is important for } \\
\text { detecting variation of different genotypes of chilli and its utilization for further breeding } \\
\text { programme. Such information may be useful for selecting the diverse parents and } \\
\text { monitoring the genetic diversity periodically to enhance breeding improvement of chilli. }\end{array}$} \\
\hline Article Info & \\
\hline $\begin{array}{l}\text { Accepted: } \\
\text { 07 May } 2019 \\
\text { Available Online: } \\
\text { 10 June } 2019\end{array}$ & \\
\hline
\end{tabular}

\section{Introduction}

Chilli (Capsicum annuum L.) $(2 \mathrm{n}=24)$ is considered as one of the most important commercial spice crop. Male sterility is extensively utilized in chilli for the development of hybrids. The genetic improvement of crop depends on the amount of genetic variability present in the population. Genetic diversity is normally assessed by common morphological traits. However, such traits are affected by effects of environment, development stage of the plant and the type of plant material and also it require several replications to establish the genotypic contributions. Hence, there is a need to go for a highly reliable and precise method for assessment of genetic variability with no environmental effects. Assessment of genetic diversity with molecular markers overcomes this problem. Various molecular markers have been used for identification of chili and to evaluate their germplasm diversity. The molecular approach for identification of plant species/varieties seems to be more effective than traditional morphological markers because it allows direct access to the DNA and makes it possible to understand the relationships between plants (Williams et al., 1990; Paterson et al., 1991).

\section{Materials and Methods}

The study on molecular analysis in CMS lines through molecular markers in chilli was 
carried out in the laboratory of Plant Biotechnology Centre Dr. Balasaheb Sawant Konkan Krishi Vidyapeeth Dapoli, Dist. Ratnagiri (M.S.) during the year 2015. A total of eight CMS lines viz, AVPP0309S, AVPP9907S, AVPP0310S, AVPP0516S, AVPP0517S, AVPP0710S, AVPP0709S, AVPP0711S and their maintainer lines AVPP0309, AVPP9907, VI060629:C05601, VI037614:TC0630, VI060632:C05661, VI046838:TC0667, VI060627:C05606 and VI060630:C05671 respectively were utilized for molecular analysis study. These eight CMS lines and their maintainer counterparts were obtained from AVRDC-The World Vegetable Centre, Taiwan. Genomic DNA was extracted from seedlings of all the 16 lines of chilli for molecular analysis. The DNA was isolated by following the protocol of Doyle and Doyle (1990). Ten ISSR primers were screened on the DNA of 16 lines of Capsicum annuum to determine the suitability of each primer for the study. The amplification reaction was performed by PCR machine. ISSR markers across the 16 lines of chilli were scored for their presence (1) or absence (0) of bands for each primer. The binary data so generated was used to estimate the levels of polymorphism by dividing the number of polymorphic bands by the total number of scored bands. The similarity coefficient analysis and dendrogram construction were carried out by using MVSP-A Multivariate Statistical Package5785 (Version 3.1).

\section{Results and Discussion}

RAPD was used to study molecular polymorphism at the DNA level in Capsicum annuum (Prince et al., 1995). The ISSR markers are multilocus, more reproducible, provide highly polymorphic fingerprints, are easy to develop in large numbers, have a simple assay, and are random, so that no prior sequence information is required. Due to these advantages; they are effective for genetic variability analysis, fingerprinting and genome mapping. Hence in the present study, ISSR markers were used to analyse the variation in chilli genotypes.

The primer wise amplification detail of the genomic DNA of 16 lines of chilli and per cent polymorphism across the 10 ISSR primers are presented in the Table 1. A total of 581 scorable DNA fragments were produced and among them 373 DNA fragments were found to be polymorphic and 208 DNA fragment was monomorphic in the CMS lines of chilli. Among the primers, UBC-857 recorded maximum (112) DNA amplicons whereas primer UBC-807 and UBC-891 recorded least number of amplicons (20).

The average per cent polymorphism in all the 16 lines across the 10 ISSR primers was found to be 64.94 per cent. Among the 10 primers UBC-807, UBC-816 and UBC-834 produced highest polymorphism i.e., $100 \%$, while the primer UBC-886 showed lowest polymorphism percentage i.e., $20 \%$.

All the 16 lines studied gave scorable DNA bands and each of the 10 random primers revealed polymorphism. Similar results were reported by Hossain et al., (2014) who done studies on the DNA fingerprinting and genetic diversity analysis of chilli germplasm using microsatellite markers. In chili genotypes, the primers produced high degree of polymorphism with an average of 64.94 per cent. Average 58 bands per primer were observed. Among the 10 primers viz., UBC807, UBC-814, UBC-816, UBC-818, UBC834, UBC-841, UBC-857, UBC-885, UBC886, UBC-891 revealed 64.94 per cent polymorphism with the maximum number of DNA fragments. The percentage of polymorphism across the chilli lines ranged from 20-100 per cent. Similar results were 
reported by Sahoo et al., (2014) who carried out the investigation to study 18 cultivars of Capsicum annuum L. using morphological and molecular markers.

Among 10 primers, seven primers showed monomorphism (UBC-814, UBC-818, UBC841, UBC-857, UBC-885, UBC-886 and UBC-891). The monomorphic bands are constant bands and cannot be used to study diversity while polymorphic bands reveal differences and can be used to examine and establish systematic relationship among the genotype. The amount of genetic variability recognized in such studies depends on the primer used and the amount of diversity among the genotype. In this study the diverse per cent of polymorphism may be because of the highly divergent lines examined. More appropriately, the chosen primers were able to recognize the genetic differences and high level of polymorphism among the 16 genotypes of chilli. Similar results were reported by Sahoo et al., (2014) who carried out the investigation to study 18 cultivars of Capsicum annuum L. using morphological and molecular markers.

The dendrogram based on Jaccard's similarity coefficient was constructed using UPGMA after analysis of banding patterns generated by all the accessions with 10 primers across the 16 genotype of chilli. The Dendrogram grouped all genotype into two main clusters of CMS lines of chilli is depicted in figure 1 .

The pair-wise Jaccards similarity co-efficients for the variation among the 16 chilli lines are presented in Table 2. The dendrogram and similarity coefficient values give an idea about the nature of the individual sample in the whole sample set. The similarity coefficient ranged from 0.375 (between lines AVPP0310S and AVPP0709S) to 0.784 (between lines AVPP0309S and AVPP0310S) indicated the distinctness of these lines.

Table.1 Primer wise amplification and per cent polymorphism of CMS lines of chilli

\begin{tabular}{|c|c|c|c|c|c|c|}
\hline $\begin{array}{l}\text { Sr. } \\
\text { No. }\end{array}$ & Primer Name & $\begin{array}{r}\text { Total No. } \\
\text { Bands }\end{array}$ & $\begin{array}{r}\text { Number of } \\
\text { monomorphic } \\
\text { bands }\end{array}$ & $\begin{array}{r}\text { Number of } \\
\text { polymorphic } \\
\text { bands }\end{array}$ & $\begin{array}{r}\text { Per cent } \\
\text { plymorphism }\end{array}$ & $\begin{array}{r}\text { Range of } \\
\text { Amplification }\end{array}$ \\
\hline 1 & UBC-807 & 20 & 0 & 20 & 100.00 & $600-1150$ \\
\hline 2 & UBC-814 & 52 & 32 & 20 & 38.46 & $400-1150$ \\
\hline 3 & UBC-816 & 25 & 0 & 25 & 100.00 & $700-900$ \\
\hline 4 & UBC-818 & 65 & 32 & 33 & 50.77 & $600-1300$ \\
\hline 5 & UBC-834 & 63 & 0 & 63 & 100.00 & $200-1300$ \\
\hline 6 & UBC-841 & 54 & 32 & 22 & 40.74 & $400-950$ \\
\hline 7 & UBC-857 & 112 & 16 & 96 & 85.71 & $150-1600$ \\
\hline 8 & UBC-885 & 102 & 64 & 38 & 37.25 & $300-1300$ \\
\hline 9 & UBC-886 & 20 & 16 & 4 & 20.00 & 785-1319 \\
\hline \multirow[t]{3}{*}{10} & UBC-891 & 68 & 16 & 52 & 76.47 & $300-1300$ \\
\hline & Total & 581 & 208 & 373 & - & $=$ \\
\hline & Average & 58.1 & 20.8 & 37.3 & 64.94 & $443.5-1226.9$ \\
\hline
\end{tabular}


Table. 2 Variation based on ISSR pooled over the 10 primers in 16 lines of chilli

\begin{tabular}{|c|c|c|c|c|c|c|c|c|c|c|c|c|c|c|c|c|}
\hline \multicolumn{17}{|l|}{ Similarity } \\
\hline & $\begin{array}{c}\text { AVPP03 } \\
\text { 09S }\end{array}$ & $\begin{array}{c}\text { AVPP99 } \\
\text { 07S }\end{array}$ & $\begin{array}{c}\text { AVPP03 } \\
10 \mathrm{~S}\end{array}$ & AVPP0516S & AVPP0517S & AVPP0710S & AVPP0709S & AVPP0711S & AVPP0309 & AVPP9907 & $\begin{array}{c}\text { VI060629: } \\
\text { C05601 }\end{array}$ & $\begin{array}{c}\text { VI037614: } \\
\text { TC0630 }\end{array}$ & $\begin{array}{c}\text { VI060632: } \\
\text { C05661 }\end{array}$ & $\begin{array}{c}\text { VI046838: } \\
\text { TC0667 }\end{array}$ & $\begin{array}{c}\text { VI060627: } \\
\text { C05606 }\end{array}$ & $\begin{array}{c}\text { VI060630: } \\
\text { C05671 }\end{array}$ \\
\hline AVPP0309S & 1.000 & & & & & & & & & & & & & & & \\
\hline AVPP9907S & 0.771 & 1.000 & & & & & & & & & & & & & & \\
\hline AVPP0310S & 0.784 & 0.692 & 1.000 & & & & & & & & & & & & & \\
\hline AVPP0516S & 0.657 & 0.568 & 0.632 & 1.000 & & & & & & & & & & & & \\
\hline AVPP0517S & 0.581 & 0.581 & 0.600 & 0.524 & 1.000 & & & & & & & & & & & \\
\hline AVPP0710S & 0.649 & 0.564 & 0.585 & 0.781 & 0.523 & 1.000 & & & & & & & & & & \\
\hline AVPP0709S & 0.409 & 0.512 & 0.375 & 0.450 & 0.478 & 0.452 & 1.000 & & & & & & & & & \\
\hline AVPP0711S & 0.634 & 0.634 & 0.578 & 0.537 & 0.659 & 0.535 & 0.523 & 1.000 & & & & & & & & \\
\hline AVPP0309 & 0.609 & 0.542 & 0.560 & 0.522 & 0.600 & 0.553 & 0.480 & 0.646 & 1.000 & & & & & & & \\
\hline AVPP9907 & 0.558 & 0.634 & 0.543 & 0.500 & 0.521 & 0.500 & 0.558 & 0.714 & 0.612 & 1.000 & & & & & & \\
\hline $\begin{array}{c}\text { VI060629: } \\
\text { C05601 }\end{array}$ & 0.561 & 0.600 & 0.511 & 0.579 & 0.591 & 0.537 & 0.600 & 0.683 & 0.583 & 0.769 & 1.000 & & & & & \\
\hline $\begin{array}{c}\text { VI037614: } \\
\text { TC0630 }\end{array}$ & 0.463 & 0.491 & 0.566 & 0.471 & 0.574 & 0.444 & 0.463 & 0.585 & 0.655 & 0.615 & 0.588 & 1.000 & & & & \\
\hline $\begin{array}{c}\text { VI060632: } \\
\text { C05661 }\end{array}$ & 0.560 & 0.529 & 0.547 & 0.396 & 0.647 & 0.426 & 0.393 & 0.596 & 0.607 & 0.509 & 0.538 & 0.696 & 1.000 & & & \\
\hline $\begin{array}{c}\text { VI046838: } \\
\text { TC0667 }\end{array}$ & 0.553 & 0.521 & 0.540 & 0.408 & 0.580 & 0.412 & 0.404 & 0.625 & 0.604 & 0.472 & 0.531 & 0.636 & 0.745 & 1.000 & & \\
\hline $\begin{array}{c}\text { VI060627: } \\
\text { C05606 }\end{array}$ & 0.568 & 0.568 & 0.622 & 0.444 & 0.471 & 0.511 & 0.438 & 0.574 & 0.528 & 0.609 & 0.543 & 0.593 & 0.574 & 0.600 & 1.000 & \\
\hline \multirow[t]{2}{*}{$\begin{array}{c}\text { VI060630: } \\
\text { C05671 }\end{array}$} & 0.558 & 0.675 & 0.543 & 0.500 & 0.587 & 0.467 & 0.457 & 0.756 & 0.580 & 0.636 & 0.643 & 0.615 & 0.596 & 0.625 & 0.644 & 1.000 \\
\hline & $\begin{array}{c}\text { AVPP03 } \\
\text { 09S }\end{array}$ & $\begin{array}{c}\text { AVPP99 } \\
\text { 07S }\end{array}$ & $\begin{array}{c}\text { AVPP03 } \\
10 \mathrm{~S}\end{array}$ & AVPP0516S & AVPP0517S & AVPP0710S & AVPP0709S & AVPP0711S & AVPP0309 & AVPP9907 & $\begin{array}{c}\text { VI060629: } \\
\text { C05601 }\end{array}$ & $\begin{array}{c}\text { VI037614 } \\
: \\
\text { TC0630 }\end{array}$ & $\begin{array}{c}\text { VI060632 } \\
: \\
\text { C05661 }\end{array}$ & $\begin{array}{c}\text { VI046838: } \\
\text { TC0667 }\end{array}$ & $\begin{array}{c}\text { VI060627: } \\
\text { C05606 }\end{array}$ & $\begin{array}{c}\text { VI060630 } \\
: \\
\text { C05671 }\end{array}$ \\
\hline
\end{tabular}


Table.3 Clustering pattern of 16 lines of chilli

\begin{tabular}{|c|c|c|l|}
\hline \multicolumn{2}{|c|}{ Cluster } & No. of genotype & \multicolumn{1}{|c|}{ Name of the genotype } \\
\hline I & IA & 5 & AVPP0309S, AVPP0310S, AVPP9907S, AVPP0516S, \\
& & & AVPP0710S \\
\cline { 2 - 4 } & IB & 10 & AVPP0517S, AVPP0309, VI037614:TC0630, \\
& & VI060632:C05661, VI046838:TC0667, AVPP0711S, \\
& & VI060630:C05671, AVPP9907, VI060629:C05601, \\
& & VI060627:C05606 \\
\hline
\end{tabular}

Fig.1 Dendrogram constructed using Jaccard's similarity coefficient

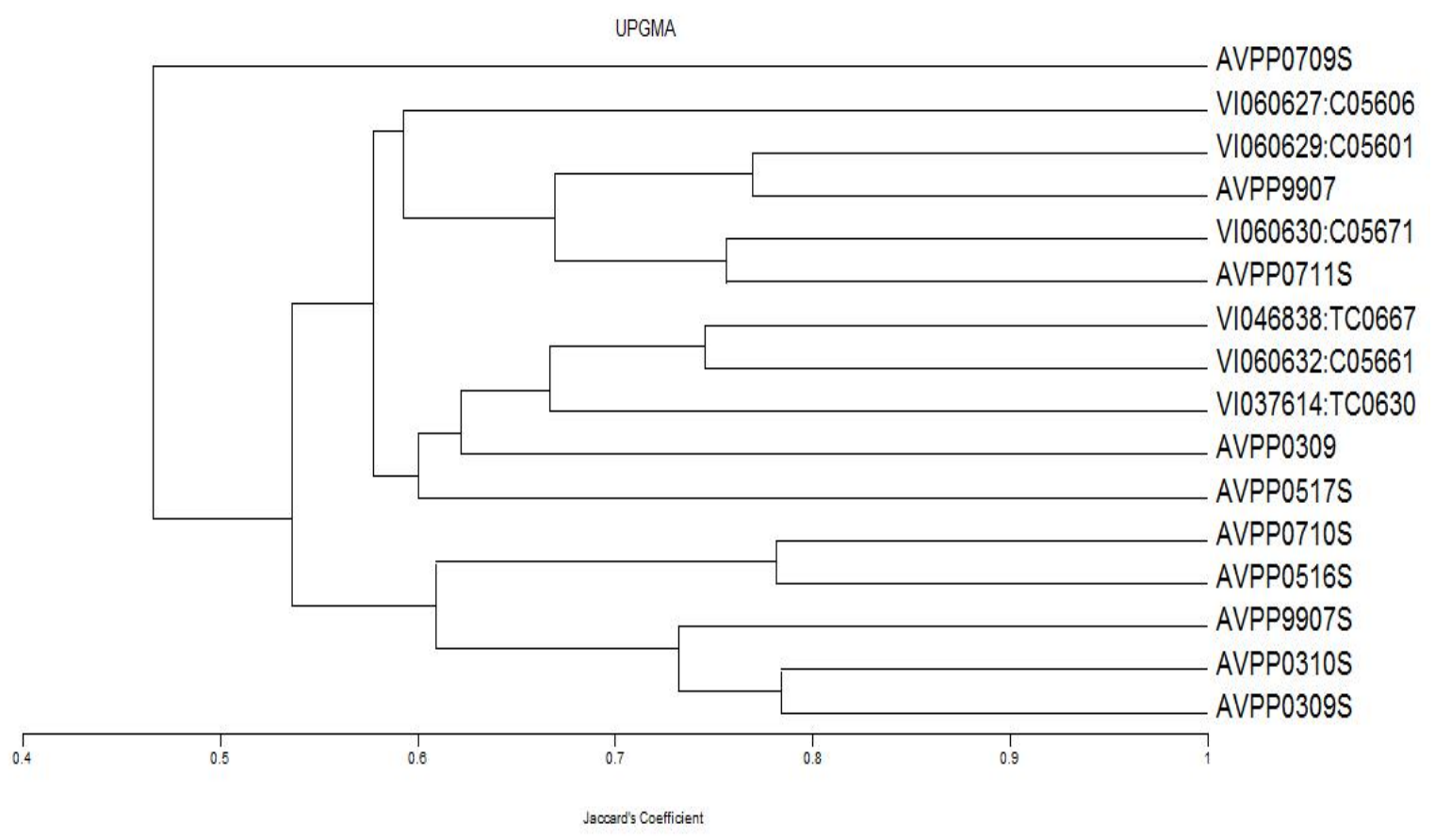

The cluster analysis was carried out based on the ISSR profile is presented in Table 3. The results based on the ISSR profile broadly grouped the 16 chilli genotype into two main clusters (I and II). First cluster (I) was formed by the two subclasses the first sub class of the first cluster containing 5 genotypes while the second sub class consists of 10 genotypes. The second cluster consists of only one line i.e. AVPP0709S. Therefore, the line AVPP0709S was found highly diverse among the 16 lines of chilli.
In conclusion, the ISSR analysis revealed substantial polymorphism in chilli. The results of the present study indicated the efficiency of ISSR markers in investigating genetic variability at molecular level, which is important for detecting variation of different genotypes of chilli and its utilization for further breeding programme. Such information may be useful for selecting the diverse parents and monitoring the genetic diversity periodically to enhance breeding improvement programmeof chilli. 


\section{References}

Doyle, J. J. and Doyle, J. L. (1990). Isolation of plant DNA from fresh tissue. Focus., 12: 13-15.

Hossain, S. M., Habiba, U., Bhuyan, S. I., Haque, M.S., Begum, S.N. and Hossain, D. M., 2014. DNA Fingerprinting and Genetic Diversity Analysis of Chilli Germplasm Using Microsatellite markers. Biotechnology, 13: $174-180$.

Paterson, A.H, Tanksley, S.D \&Sorreis, M.E. 1991. DNA markers in plant improvement. Advances Agronomy. 46: 39-90.

Prince, J.P., Lackney V.K., Angeles C.,
Blauth J.R. and Kyle M.M.. 1995. A survey of DNA polymorphism within the genus Capsicum and the fingerprinting of pepper cultivars. Genome 38: 224-231.

Sahoo, L. P., Mohanty, S. K. and Rout, G.R. 2014. Profiling of 18 cultivars of Capsicum annuum L. using morphological and molecular markers. Acta Advances in Agricultural Sciences Volume 2, Issue 8:08-17.

Williams, J.G.K, Kubelik, A.R, Livak, K.J, Rafalski, J.A and Tingey, S.V. 1990. DNA polymorphisms amplified by primers are useful as genetic markers. Nuclic Acids Research. 18: 65316535 .

\section{How to cite this article:}

Vinodhini, M., V.V. Dalvi, S.S. Desai and Sawardekar, S.V. 2019. Genetic Diversity Analysis in CMS Lines of Chilli (Capsicum annuum L.). Int.J.Curr.Microbiol.App.Sci. 8(06): 649-654. doi: https://doi.org/10.20546/ijcmas.2019.806.075 